\title{
The Leadership Capacity of the Principal in Improving the Quality of Learning During the Covid- 19 Pandemic
}

\author{
Muthahharah Thahir*, Aan Komariah, Kholifatul \\ Husan Asri, Widiawati Widiawati \\ Educational Administration Department, School of \\ Postgraduate Studies \\ Universitas Pendidikan Indonesia \\ Bandung, Indonesia \\ *muthahharah_thahir@upi.edu
}

\author{
Cucun Sunanengsih \\ Primary Teacher Education Study Program \\ Universitas Pendidikan Indonesia \\ Bandung, Indonesia
}

\begin{abstract}
This article aims to explain the leadership capacities that a school principal needs to improve the quality of learning, especially during the Covid-19 pandemic. It is because of that The Covid-19 virus that is currently globalizing does not only have an impact on human health. The time of the Covid 19 pandemic which is currently shaking the world has also had an impact on every other area of life. The education sector is not immune from this impact. The virus that is fast spreading requires everyone to keep a distance, many jobs are closed by working from home. In the field of education, Covid 19, which has rocked so badly, requires that education be held by implementing online learning using various media. This article is an analysis of phenomena that occur based on relevant theories. The method used is a theoretical review. The results of the analysis of several theories concluded that the principal is the figure most responsible for maintaining and improving the quality of education in schools. In the midst of a pandemic, school principals have an increasing responsibility so that they can continue to carry out quality educational practices. During this period, the leadership capacity of school principals is needed so that they are still able to manage their educational institutions and the quality of education is maintained amid the pandemic. In this case, the principal must be able to formulate strategic steps, be able to apply a situational leadership style, be able to apply crisis / emergency leadership, be able to make decisions responsively.
\end{abstract}

Keywords-leadership capacity, quality of education, pandemic Covid-19

\section{INTRODUCTION}

Currently, the world is being shocked by the presence of a deadly virus, namely the corona virus or Covid-19. The ongoing COVID-19 is a continuous pandemic that started in December 2019 in Wuhan, China and was declared a pandemic by WHO on 11 March 2020 [1]. The Covid-19 virus which is currently globalizing does not only have an impact on human health. Various actions were taken to reduce the outbreak, including the use of face masks, hand hygiene and selfquarantine, surface cleaning and the cancellation or postponement of various national and international activities. The pandemic that occurs has an impact on the economic and social activities carried out by the community. Social restrictions are carried out to reduce the spread of the Covid-19 virus.

The period of the Covid 19 pandemic which is currently shaking the world has also had an impact not only on health, the social and economic system, butualso every other area of life was affected, including the field of education. The main effects of the pandemic include economic and social instability, racism and xenophobia among people against Chinese, Southeast Asian and East Asian as well as the spread of misinformation and various online conspiracy theories about COVID-19 [2]. The pandemic period has brought many changes in the field of education. The World Bank said that the Covid-19 pandemic was now threatening and had great potential to make education outcomes worse. The pandemic has had a huge impact on education by closing schools almost everywhere in the world. The virus, which is amazingly fast spreading, requires everyone to keep their distance, many jobs are closed, working from home. In the field of education, to break the chain of the spread of Covid-19, the government changed the education system, which was originally carried out in schools to become learning from home. Media that can be used when studying online are WhatsApp, google classroom, zoom and so on. As explained, the Corona Virus Disease 2019 (COVID-19) outbreak in various countries has shifted traditional face-to-face teaching to online education platforms, which directly impacts the quality of education [3]. It was also explained that, during the pandemic, schools were indeed closed off, but the learning process had to continue. So far, no online learning has been carried out simultaneously [4] During the pandemic, online learning has now been carried out in almost all over the world [5]. In addition to learning, the 
selection process for admission of new students, such as in tertiary institutions, is carried out online until the introduction of campus life is also done online. This gives a signal that even though a pandemic occurs, the process of educational activities must continue. Therefore, each education unit must strive to maintain the quality of education amid the pandemic that occurs.

One of the schools responsible for maintaining the quality of education in the midst of this pandemic is the principal. The principal is the figure most responsible for maintaining and improving the quality of education in schools. The role of school principals as learning leaders in schools is an important key in maintaining the quality of school education, especially during a pandemic. As leaders, in this pandemic era, school principals have more responsibility than before. The principal must ensure that all teachers are capable of and optimally implementing online learning. The principal is also responsible for ensuring that all students are well served during a pandemic. In fact, the principal must also be able to involve and collaborate between teachers and parents of students to work together so that students remain facilitated in learning at home. This is because the impact of studying at home is also felt by parents who also have more burdens because they must become teachers at home $[6,7]$.

The success of each educational unit during this pandemic depends very much on the leadership capacity of the leader. Because the principal is the leader in his institution, he must continue to achieve the institution's goals even though the pandemic is occurring. Changing global conditions such as those currently occurring require increasing efficiency requirements, the urgent need to continue learning and advanced digital technology requires an important role in educational leadership [8]. As described by Pont et. al that Effective school leadership is essential to improve the efficiency and equity of schooling [9] and also the quality of education [10].

Therefore, this article will describe the leadership capacities a leader must have during a pandemic so that the quality of education can be maintained and improved.

\section{LITERATURE REVIEW}

\section{A. Covid-19 and Its Impact on Education}

COVID-19 stands for coronavirus disease and is even referred to as novel coronavirus 2019 or '2019-nCoV' [11]. The COVID-19 virus is linked to Severe Acute Respiratory Syndrome Coronavirus 2 (SARS-CoV) which can also be fatal [12]. This new virus can be transmitted in just a few minutes by droplets or even touching an infected metal or other material surface from someone who has breathing problems. Although the elderly and children are very susceptible, no one is immune to this new infectious disease after it has invaded the body, so everyone is susceptible to its devastating effects $[11,12]$. Due to vulnerability even in school environments, thousands of school closures have been implemented worldwide due to
COVID-19. As of 06 April 2020, UNESCO reported that there were $1,576,021,818$ students affected from $91.3 \%$ of the total students enrolled in 188 countries at all levels of learning [13]. Covid-19 causes education to be done online to break the chain of Covid-19 itself. The implementation of online learning is mostly carried out using the WhatsApp application [14-16] with the consideration that on average teachers and students or parents of students have this application on their respective gadgets. This application has a WhatsApp Group feature so that teachers and students can discuss and share documents with each other.

\section{B. Principal's Leadership Capacity}

Capacity is often defined as the ability to do something [17]. Capacity is a quality that enables people, individually and collectively, on a regular basis to learn from the world around them and to apply this learning to new situations so that they can continue on the path to their goals in an ever-changing context [18]. Capacity can be viewed as the potential for objects, individuals, or groups [19], or even as "habits of mind" [18]. Personal capacity is defined as "a mixture of all values, assumptions, beliefs and embedded practical knowledge brought by actors and from the professional networks and knowledge base they connect to [20]. A simple definition of organizational capacity is" ... as the ability to perform functions, solve problems, and set and achieve objectives [21].

Meanwhile, leadership is defined as "the process (action) influencing the activities of an organized group in its quest towards goal setting and goal achievement. can be influenced by whoever is involved [22]. Principals are leaders in schools. Principals, through their actions, can become powerful multipliers of effective teaching and leadership practices in schools. And these practices can contribute a lot to student success [23]

Leadership capacity is about creating the conditions within schools for growth, self-renewal, and the development and distribution of leadership throughout the school organization [24]. Therefore, the leadership capacity of the principal is all abilities, knowledge and skills possessed by the school to influence all school members to jointly achieve school goals.

The school education process is something that must be carried out effectively and efficiently. Especially in the midst of a pandemic, implementing the education process effectively and efficiently is a challenge that must be faced by a head of school. The effectiveness of the educational process and its outcomes all reflect the leadership of the principal [25].

\section{Quality of Education}

The pandemic that occurs demands that quality education practices can still be implemented. In a definition, it is explained that quality is defined as "conformance to standards and specifications" [26] or fitness for use [27]. Quality is described as a unit of goodness that is packaged into a product or service [28]. The quality possessed by an organization is one of the factors for achieving organizational success [29]. In 
addition, quality is one of the competitive priorities [30]. Another definition explains that quality is an advantage, quality is value, quality is in accordance with specifications, quality means meeting and or exceeding customer expectations [31].

The need for quality education is the single most important thing and quality makes the difference between success and failure [32]. The quality of education is the conformity with the objectives, which is related to all the characteristics of education (input, process, and output) [33]. Research on education quality is primarily focused entirely on input, process, or output [34-36]. In connection with a pandemic, the quality of education both in terms of input, process and output must be considered.

\section{DISCUSSION}

Coronavirus disease (Covid-19) is a virus that is shaking the world. The big event triggered by this infectious disease is beyond the predictions of many circles. Currently, all sectors are affected, including the world of education. Academic leaders responded by moving their educational and related activities online. The decision to pivot to distance learning is made quickly. In the context of educational organizations, educational leadership is defined as an influencing process to move education implementers so that the educational goals that have been previously set can be achieved effectively and efficiently.

Leadership, the key to school success, means that the role of the principal is especially important in the success of the school in achieving the goals of a successful school if they understand. The existence of the school as an organization that is overly complex and unique and is able to carry out the role of the leader or principal as a person who is given the responsibility to lead the school.

In the midst of a pandemic, school principals have greater responsibility so that they can continue to carry out quality educational practices.

The implementation of the roles and responsibilities of school principals during this pandemic will certainly not be optimal if they are not accompanied by the capacity of the principal in implementing his leadership. Therefore, principals need good leadership skills by mastering competences as school principals [37]. The principal as a leader has a very important role in developing the quality of education in schools, therefore he must strive to develop his leadership capacity effectively at various levels, from himself, others, to the organization, by fulfilling his roles and responsibilities $[38,39]$.

During this pandemic, the leadership capacity of school principals is needed and must be further improved so that they are able to manage their educational institutions and the quality of education is maintained in the midst of a pandemic. During the Covid 19 pandemic, the process of organizing and improving the quality of school education will be a challenge for school principals to devote all their abilities to implementing their leadership skills, and implementing their ideas and ideas so that the education process in schools continues to run according to the goals and the quality of the school increases [40]. This challenge will test the extent to which school principals are able to use their leadership capacity in the midst of an outbreak. The leadership capacity of school principals in improving the quality of education during the Covid 19 pandemic is an ability and skill that must be possessed by school principals as an effort, art, technique carried out by school principals to mobilize all school components to jointly create good quality schools in short term and long term. In connection with this, the principal must be able to have a number of capacities. Among them are 1) able to formulate strategic plan, 2) able to implement situational leadership style, 3) able to apply crisis / emergency leadership, and 4) able to make responsive decisions.

\section{A. Formulating Strategic Plan}

As a school principal, compiling strategic steps is something that must be done especially in the midst of a pandemic that demands that school principals be prepared with strategic steps so that the education delivery process can continue to be carried out in quality In devising strategic steps, the principal balances strategic and operational leadership. Common moral visions and goals anchor their decisions and align operations with strategy [41]. In this case, the strategic steps prepared by the principal are a series of systematic plans [42] but can also mean tactics and art in war [43]. so that with this strategic plan the principal can implement a strategy in accordance with the conditions and demands of the existing environment.

In the study of integrated quality management, the process approach must fulfill the Plan, Do, Check and Action (PDCA) activities this idea was pioneered by Edward Deming. In relation to education in schools. Quality education is obtained from a management process that is carried out consistently from the stages of preparation, implementation, and follow-up [44]. These stages are carried out continuously to ensure the quality of a school. Therefore, compiling strategic steps is the first step for school principals in the planning stage so that they are able to carry out quality education processes in the midst of a pandemic. In this case, the principal certainly has to identify needs so that he is able to formulate an implementable strategic plan. The principal must be able to re-compile the School Budget Work Plan to adapt it to the pandemic conditions that have occurred. By compiling a strategic plan, it is hoped that the educational process in the midst of a pandemic can continue to be carried out optimally.

\section{B. Implementing Siatuational Leadership}

The pandemic that occurs is a challenge for school principals so that school principals must have the ability to apply a national leadership style. Situational leadership theory proposes that effective leadership requires a rational understanding of a situation and an appropriate response $[45,46]$. Situational leadership focuses on conformity or 
readiness of followers. This cycle can be illustrated by a bellshaped curve superimposed on the four leadership quadrants [47], as shown in the following figure.

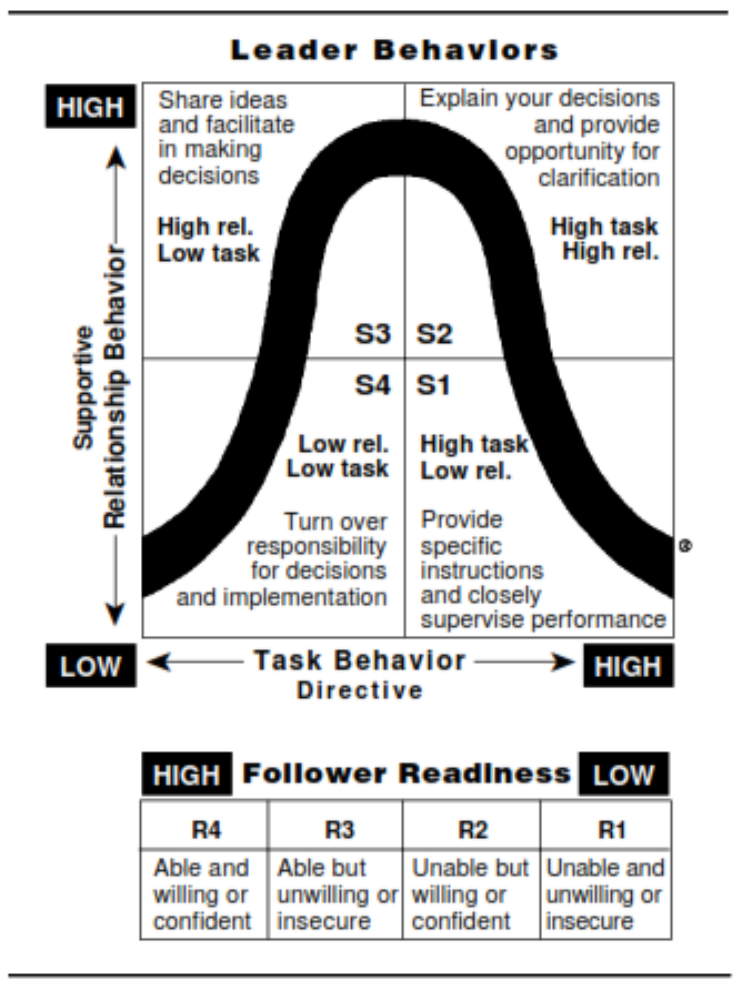

Fig. 1. Model situational leadership Hersey and Bkanchard.

Principal's situational leadership style can be measured through four leader behaviors in the Contingency-Situational Model [48].

- Telling / dictating: The leader's ability to define the roles required to perform a task and tell followers what, where, how, and when to perform the tasks.

- Selling / selling: The leader's ability to provide structured instructions for his subordinates must also be supportive.

- Participating: The interaction between leaders and subordinates where leaders and subordinates share in decisions about how best to complete the task well.

- Delegating / delegation: The leadership's ability to hand over responsibility for the implementation of work to subordinates in order to be able to perform work effectiveness.

The pandemic that has occurred that encourages the implementation of online learning, the principal must be able to understand every ability possessed by all school members to carry out online learning. Therefore, with a national leadership style the principal is able to apply the right strategy so that the learning process can be carried out effectively.

\section{Implementing Crisis Leadership}

Crisis is basically an unprecedented event which does not give us much time to prepare [49]. The pandemic that occurs can be likened to a crisis. In times of crisis, leaders play a large role either in maintaining effective communication, building trust, increasing productivity or maintaining quality [50]. Leading academic institutions in crisis is a challenge that must be faced by school principals, given the role and influence of leaders enlarged at times of change. There are a number of competencies for crisis leadership, namely decision making, communication, creating organizational capabilities, maintaining an effective organizational culture, managing many constituents, and developing human resources [51]. Therefore, it is important for school principals to be able to implement crisis leadership. Crisis management is a process by which an organization handles disruptive and unexpected events that threaten to harm the organization or its stakeholders [52].

\section{Make Decisions Responsively}

The quality of education and quality of education during this pandemic can be carried out and maintained properly if the leadership of the principal can be in the right role to be able to make himself a solver and an appropriate and wise policy maker [53]. The principal must be able to identify and analyze each situation so that his responsibilities can be carried out properly. So that the school coconuts in schools are still able to maintain the quality and quality of education properly. The success of an organization, such as a school, is highly dependent on the quality of decisions made by its leaders $[54,55]$. The success of a school really depends on the quality of the decisions made by a leader. Effective principals involve teachers in decision making [56-58] and leadership styles are largely related to decision-making styles [59].

The pandemic that occurred requires the principal to be able to make good decisions. Principals must consider various impacts (individual, organizational, well-being, learning, service provision, performance, employment, financial implications, resource management and business sustainability) while keeping everyone in mind. To make effective decisions, they must know the intricacies and peculiarities of their context, but also best practices occurring elsewhere and the best available evidence of what might work [60].

\section{CONCLUSION}

The Covid-19 pandemic has an impact not only on health, but every area of life is affected, including the field of education. The pandemic that occurred demands that the education process be held online. This is a challenge and responsibility for school principals to maintain the quality of education in the midst of a pandemic. The principal must have a number of capacities and apply his leadership capacity so that he is able to run the wheels and manage education optimally. Therefore, the leadership capacity of school principals in improving the quality of education in each education unit during the Covid 19 pandemic is a number of skills and 
abilities as well as a systematic effort by the principal of kindergarten in carrying out his leadership during the Covid 19 pandemic so that the quality of education can be maintained. This is done to maintain the quality that has been achieved and to try to improve the quality of the education unit so that it is better in the future. These capacities include: 1) being able to formulate strategic steps, 2) being able to apply a situational leadership style, 3) being able to apply crisis / emergency leadership, and 4) being able to make responsive decisions.

\section{REFERENCES}

[1] Sunitha B K, D. V. A.. COVID -19: Current Pandemic and Its Societal Impact. International Journal of Advanced Science and Technology, 2020 Volume 29(5s), $432-439$.

[2] Agarwal V., Sunitha B.K. COVID - 19: Current pandemic and its societal impact. International Journal of Advanced Science and Technology. 2020. Volume 19(5s), $432-439$.

[3] Chen, T., Peng, L., Yin, X., Rong, J., Yang, J., \& Cong, G.. Analysis of User Satisfaction with Online Education Platforms in China during the COVID-19 Pandemic. In Healthcare. 2020, Volume 8(3)

[4] Sun, L., Tang, Y., \& Zuo, W. Coronavirus Pushes Education Online. Nature Materials, 2020, Volume 19(6), 687-68

[5] Goldschmidt, K. The COVID-19 Pandemic: Technology Use to Support the Wellbeing of Children. Journal of Pediatric Nursing. 2020.

[6] Arwen. Desri. Student Learning Motivation Influences The Development Of The Corona Virus Pandemic (COVID 19). International Journal of Advanced Science and Technology, 2020. Volume 29(9s), $4911-4925$

[7] Sunitha V, G Anburaj, M Sandra Carmel Sophia, Gopichand G. From Epidemic to Pandemic-Covid-19-Psychological, Social and Environmental Impact-A Qualitative Study.International Journal of Advanced Science and Technology, 2020, Volume 29(7), 4883-4893.

[8] Kin, T. M., \& Kareem, O. A. School leaders' Competencies that make a difference in the Era of Education 4.0: A Conceptual Framework. International Journal of Academic Research in Business and Social Sciences, 2019, Volume 9(4).

[9] Pont, B., Nusche, D \& Moorma, H.. Improving School Leadership, Case Studies on System Leadership, OECD Publishing. 2008, Volume 2.

[10] Rosmaniar, W., \& Marzuki, S. C. B. H. Headmaster Instructional Leadership and Organizational Learning on the Quality of Madrasah and the Quality of Graduates the State Madrasah Aliyah at Jakarta Capital Region. Higher Education Studies, 2016, Volume 6(1), 159-168.

[11] Bender, L. Key Messages and Actions for COVID-19 Prevention and Control in Schools. 2020, Availabe from https://www.unicef.org/romania/documents/key-messages-and-actionscovid-19-prevention-and-control-schools

[12] Meng, L., Hua, F., \& Bian, Z. (2020). Coronavirus Disease 2019 (COVID-19): Emerging and Future Challenges for Dental and Oral Medicine. Journal of Dental Research. 2020. DOI: https://doi.org/10.1177/0022034520914246

[13] Toquero, C. M. Challenges and Opportunities for Higher Education Amid the COVID-19 Pandemic: The Philippine Context. Pedagogical Research, 2020, Volume 5(4)

[14] Dewi, W. A. F. Dampak Covid-19 terhadap implementasi pembelajaran daring di Sekolah Dasar. Edukatif: Jurnal Ilmu Pendidikan, 2020, Volume 2(1), 55-61

[15] Gunawan, G., Suranti, N. M. Y., \& Fathoroni, F.. Variations of Models and LearningPlatforms for Prospective Teachers During the COVID-19 Pandemic Period.Indonesian Journal of Teacher Education, 2020, Volume 1(2), 61-70

[16] Purwanto, Agus .Masduki Asbari, Mochammad Fahlevi, Abdul Mufid, Eva Agistiawati, Yoyok Cahyono, Popong Suryani. Impact of Work From Home (WFH) on Indonesian Teachers Performance During the Covid-19 Pandemic : An Exploratory Study. International Journal of Advanced Science and Technology,2020, Volume 29(05), 6235 -6244

[17] Huggins, K. S., Klar, H. W., Hammonds, H. L., \& Buskey, F. C. Developing Leadership Capacity in Others: An Examination of High School Principals' Personal Capacities for Fostering Leadership. International Journal of Education Policy and Leadership, 2017, Volume 12(1), n1

[18] Stoll, L.. Capacity building for school improvement or creating capacity for learning? A changing landscape. Journal of Educational Change, 2009, Volume 10, 115-127.

[19] Newmann, F., King, M.B., \& Youngs, P. Professional development that addresses school capacity: Lessons from urban elementary schools. American Journal of Education, 2000, Volume 108(4), 259-299

[20] Mitchell, C., \& Sackney, L. Profound improvement: Building learning community capacity on living-system principles (2nd ed.). New York, NY: Routledge. 2011

[21] Fukuda-Parr, Lopes, and Malik. Capacity for The Development, 8 New Solution to Old Problemens. UK and USA.: Eartgscan Oublication Ltd. 2002.

[22] Bass, B. M. "From transactional to transformational leadership: Learning to share the vision”. Organizational Dynamics. Winter, 1990. 19-31

[23] Scott, D.. School Leadership: A Primer for Policymakers. Special Report. Education Commission of the States. 2018.

[24] Williams, H. S. Leadership Capacity--A Key to Sustaining Lasting Improvement. Education, 2009, Volume 130(1).

[25] Hill-Berry, N. P.. Expanding Leadership Capacity toward Social Justice. Research in Educational Administration \& Leadership, 2019 Volume 4(3), 720-742.

[26] Crosby, P.. Quality is Free. New York: McGrawhill. 1979

[27] Juran, J.M. \& Godfrey, A.B. (Eds), Juran's Quality Handbook, New York: McGraw-Hill. 1999

[28] Ghobadian, A., Speller, S. and Jones, M. Service Quality: Concepts and Models, International Journal of Quality \& Reliability Management, 1994, Volume $11 \quad$ (9), 43-66. DOI: https://doi.org/10.1108/02656719410074297

[29] Sharabi, M., \& Davidow, M.. Service quality implementation: problems and solutions. International Journal of Quality and Service Sciences, 2016, Volume 2(2), 189-205. doi:10.1108/17566691011057357

[30] Morales Espinoza, M.. Assessing the cross-cultural applicability of a service quality measure A comparative study between Quebec and Peru", International Journal of Service Industry Management, 1999, $\begin{array}{lllll}\text { Volume } & 10 & (5), & 449-468 . & \text { DOI: }\end{array}$ https//:doi.org/10.1108/09564239910288987

[31] Pariseau, S. \& McDaniel, J. Assessing service quality in schools of business. International Journal of Quality \& Reliability Management, 1997. Volume $14 \quad$ (3), 204-218. DOI: doi.org/10.1108/02656719710165455

[32] Steyn, G. M. Focusing on guiding principles of quality to redesign educational institutions. South African Journal of Education, 2001, Volume 21(1), 17-24

[33] Garira, E.. A Proposed Unified Conceptual Framework for Quality of Education in Schools. Sage Open, 2020. DOI: 10(1), 2158244019899445.

[34] Giannini, M. Organization and quality in school education. ProcediaSocial and Behavioral Sciences, 2015, Volume 174(2015), 1735- 1739.

[35] Jenjekwa, V. Access and quality in education in resettlement schools The case study of Zvivingwi secondary school in Gutu District, Masvingo province in Zimbabwe. International Journal of Educational Administration and Policy Studies, 2013. Volume 5(2), 15-21.

[36] Mazise, A.. Challenges and prospects of quality primary education in Zimbabwean rural schools: a case study of Kadoma. University of Fort Hare, Republic of South Africa. 2011 
[37] Patterson, W. G. How to Obtain A Principalship, A Journal of Educational Strategies, Issues and Ideas, 2016, Volume 44 (5), 310-314. DOI: https://Doi.Org/10.1080/00098655.1970.11478391

[38] Nanda, Vivek. Quality Management System Handbook for Product Development Companies. Florida: Crc Press. 2005. DOI: https://doi.org/10.1201/9781420025309.

[39] Sturm, R. E., Vera, D., \& Crossan, M. The Entanglement Of Leader Character And Leader Competence And Its Impact On Performance. The Leadership Quarterly. 2016, Volume xxx, 1-17. DOI: https://Doi.Org/10.1016/J.Leaqua.2016.11.007

[40] Northouse, P. G. Leadership: Theory and practice. Los Angeles, CA: SAGEPublications. 2013.

[41] Netolicky, Deborah M. School leadership during a pandemic: navigating tensions. Journal of Professional Capital and Community. 2020. DOI 10.1108/JPCC-05-2020-0017

[42] Bell, L. School Leadership \& Management: Formerly School Organization, From Symphony To Jazz: The Concept Of Strategy In

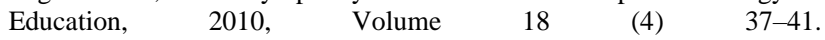
Https://Doi.Org/10.1080/13632439869420

[43] Botha, R. J. N., \& Triegaardt, P. K. P. (2017). Distributive Leadership As Management Strategy For School Effectiveness : The Place And Role Of The Oscar Coaching Model In South, African Schools, Journal of Social Sciences, 2017, Volume 40 (2): 251-260, DOI: Https://Doi.Org/10.1080/09718923.2014.11893322

[44] Cheng, Y. C. Quality Assurance In Education: Internal, Interface, And Future, Quality Assurance in Education Journal, 2003, Volume 11(4), 202-213. DOI:https://doi.org/10.1108/09684880310501386.

[45] Graeff, C. L. Evolution of situational leadership theory: A critical review. The Leadership Quarterly, 1997, Volume 8(2), 153-170. DOI:10.1016/S1048-9843(97)90014-X

[46] Grint, K. (2011). A history of leadership. In A. Bryman, D. Collinson, K. Grint, B. Jackson \& M. Uhl-Bien (Eds.), The SAGE handbook of leadership Thousand Oaks, CA: Sage. 2011. 3-14.

[47] Schermerhorn, J. R. Situational leadership: conversations with Paul Hersey. Mid American Journal of Business, 1997, Volume 12, 5-12.

[48] Hersey, P., \& Blanchard, K. H. Management of organization behavior: Utilizing human resources. 3rd ed. Englewood Cliffs, N. J.: Prentice Hall, Inc. 1997.
[49] Bhaduri, R. M. Leveraging culture and leadership in crisis management. European Journal of Training and Development. 2019, DOI:10.1108/ejtd-10-2018-0109

[50] Lockwood, N.R. (2005), “Crisis management in today's business environment: HR's strategic role”, SHRM Research Quarterly, 2005. 110, available from: www.shrm.org/research/articles/articles/ documents/1205rquartpdf.pdf

[51] Wooten, L.P. and James, E.H. (2008), Linking crisis management and leadership competencies: the role of human resource development, Advances in Developing Human Resources, 2008, Volume 10 (3), 352 379, DOI: $10.1177 / 1523422308316450$

[52] Bundy, Jonathan; Pfarrer, Michael D.; Short, Cole E.; Coombs, W. Timothy. "Crises and Crisis Management: Integration, Interpretation, and Research Development".Journal of Management, 2017, Volume 43(6): 1661-1692

[53] Hazizah, N. (2020). Leadership Headmaster in Improving the Quality of PAUD in the New Normal Period. SPEKTRUM: Jurnal Pendidikan Luar Sekolah (PLS), 2020, Volume 8(2), 142-146.

[54] Eberlin, R. J., and B. C. Tatum. Making Just Decisions: Organizational Justice, Decisionmaking, and Leadership. Management Decision, 2008 Volume 46 (2): 310-329. DOI:10.1108/002517 40810854177

[55] Robbins, S., R. Bergman, I. Stagg, and M. Coulter. Management. 5th ed. Frenchs Forest, NSW: Pearson Prentice Hall. 2009.

[56] Barnett, K., \& McCormick, J. Vision, relationships and teacher motivation: A case study. Journal of Educational Administration. 2003, Volume 41(1), 55-73.

[57] Williams, R. Leadership for School Reform: Do Principal Decisionmaking Styles Reflect a Collaborative Approach?. Canadian Journal of Educational Administration and Policy, 2006, Volume 53: 1-22.

[58] Pashiardis, P. Group Decision Making: The Role of the Principal. The International Journal of Educational Management, 1993, Volume 7 (2): $8-11$.

[59] Kao, P.-H., and H. Kao. Taiwanese Executives' Leadership Styles and their Preferred Decision-making Models Used in Mainland China. Journal of American Academy of Business, Cambridge 20076, Volume 10 (2): 71-79.

[60] Netolicky, D. M. School leadership during a pandemic: navigating tensions. Journal of Professional Capital and Community. 2020. 